\title{
Is Brca-Associated Protein (Bap1) A New Drug Target to Combat Metastatic Uveal Melanoma?
}

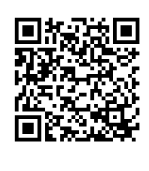

\author{
Abigail R Bland and Rhonda J Rosengren* \\ Department of Pharmacology and Toxicology, University of Otago, New Zealand
}

Submission: August 17, 2018; Published: September 10, 2018

*Corresponding author: Rhonda J Rosengren, Department of Pharmacology and Toxicology, 18 Frederick Street, University of Otago, Dunedin, New Zealand, 9016; Tel: +64-3-479914; Fax +64-3-4799140; Email: rhonda.rosengren@otago.ac.nz

\begin{abstract}
This is a review discussing the role of BRCA -associated protein 1 in the development of metastatic uveal melanoma. There is recent in vitro and in vivo evidence to suggest that BRCA-associated protein 1 could be a potential drug target to increase the survival in patients who develop metastatic uveal melanoma. Evidence for the utility of BRCA-associated protein 1 target treatments will be discussed.
\end{abstract}

Keywords: BAP1; Uveal melanoma; E2F1; Host cell factor 1; Cell cycle arrest; OCM1A xenografts

Abbreviations: BRCA-Associated Protein 1 (BAP1); Host Cell Factor 1 (HCF-1); Cell Cycle Arrest; OCM1A Xenografts

\section{Introduction}

Uveal melanoma is a malignant cancer of the eye found primarily in Caucasian adults with 2-8 million cases reported per year [1]. This type of malignancy is found in the iris, choroid or the ciliary body of the eye and ciliary body melanoma has the worst prognosis, while iris melanoma has the best $[2,3]$. When the tumor is controlled locally survival is high [4,5]. However, systemic metastasis within 5 years of diagnosis occurs in 40 $50 \%$ of all patients, leading to death in approximately $30 \%$ of patients. The liver is the primary site of metastasis and the median survival of patients who develop liver metastasis is 5-6 months, irrespective of their treatment [1]. Furthermore, the overall mortality rate in all uveal melanoma patients is $62 \%$ and $90 \%$ within 5 and 15 years, post diagnosis, respectively [6].

Cytogenetic features can also play a role in the prognosis of uveal melanoma where abnormalities in chromosome $1,3,6$ and 8 can result in a poor prognosis. This includes whole or partial deletion of chromosome 3 , the gain of the long arm of chromosomes 6 and 8 and the loss of the short arm of chromosome 1 [5]. Typical cutaneous melanomas are characterized by mutations in genes such as BRAF, NRAS and NF1, however, uveal melanoma is usually associated with other mutations. These include BRCA-associated-protein-1 (BAP1), GNA11, GNAQ, SF3B1 and EIF1AX [6]. The BAP1 protein is a common germline mutation that is inherited within families.

\section{Discussion}

\section{BAP1 and uveal melanoma}

Non-truncating and truncating mutations in the BAP1 gene have been identified in 18 to $45 \%$ of uveal melanoma tumors [7-9]. In a large -scale retrospective study, 4.9\% of patients presented with a BAP1 mutation and they also had larger tumors (15.9 vs. $12.3 \mathrm{~mm}, \mathrm{p}<0.01$ ) and a greater occurrence of metastasis $(71.4 \%$ vs. $18 \%, \mathrm{p}<0.01)$ compared to those who did not present with a mutation [10]. Furthermore, downstream signaling of BAP1 was lost in cancer due to either the loss of BAP1 in the nucleus (due to a BAP1 mutation, loss of heterozygosity) or due to the localization in the cytoplasm, where it is unable to produce its tumor suppressing activity [11]. Moreover, a KaplanMeier analysis of 60 patients showed that the presence of a BAP1 mutation or the absence of BAP1 (through chromosome 3 monosomy) were both significantly associated with a reduction in overall survival [12]. Similar findings were reported, as BAP1 mutations were associated with a significant decrease in progression free survival when compared to wild type tumors (43.2 vs. 94 months, respectively, $\mathrm{p}<0.01$ ) [13]. Thus, BAP1 mutations were frequently associated with highly metastatic uveal melanoma tumors and therefore, downstream pathways could be considered potential targets. 


\section{Cell cycle dysregulation and uveal melanoma}

BAP1 depletion is associated with aggressive metastatic uveal melanoma tumors, but the exact mechanism by which BAP1 knockdown increases metastasis is unknown [14]. It has been hypothesized [15] that in BAP1 depleted cancers the cell cycle has become unregulated and although there is no increase in cell proliferation, the tumor could be the result of a delayed but permissive G1/S checkpoint. This would allow damaged and cancerous cells to enter and progress through the cell cycle instead of undergoing apoptosis. Cell cycle regulation is vital for ensuring that damaged cells do not multiply, and this is controlled by many transcription factors and proteins. One such transcription factor is E2F1, which promotes cell cycle progression through its involvement in the G1-S phase transition [16]. Host cell factor 1 (HCF-1), a chromatin-associated protein that is known to interact with BAP1 [17-19], recruits histone methyltransferases to the E2F1 promoter and thus enables transcription of E2F1 target genes.

However, ubiquitination of HCF-1 inhibit its activity on E2F1 and prevents cell cycle progression. It is thought that BAP1 can deubiquitinate HCF-1 preventing HCF-1 inhibition and therefore, could potentially indirectly promote cell cycle activation [20]. Furthermore, others have claimed that dysregulation of the cell cycle, through a disruption in E2F regulation, could be involved in the development of uveal melanoma [21]. This was supported by research that showed that, in BAP1 depleted OCM1 and OM431 human uveal melanoma cells, all E2F1 target genes (p107, SKP2, Cyclin D and Cyclin E among others) were significantly downregulated [22]. Thus, BAP1 regulated E2F1 and had an indirect effect on the regulation of genes expressed during the $S$ phase. The effect of BAP1 knockdown on growth and migration was also examined. Cell migration was significantly reduced in the cells with knockdown of BAP1, which suggested that BAP1 may also play a role in the regulation of cell migration -associated genes. BAP1 depletion was also associated with a significant decrease in the number of soft agar colonies in both OCM1 and OM431 cell lines and in OCM1 cells with BAP1 knocked down there was a significantly slower cell cycle progression and an arrest of cells in the S phase [22].

\section{Depletion of BAP1 and uveal melanoma tumorigenicity}

Dysregulation of the cell cycle is currently the hypothesized theory for the development of BAP1 depleteduveal melanoma tumors. To examine this in an in vivo model, NOD- SCID mice were injected with BAP1 deficient or control uveal melanoma cells (OCM1A), which formed xenograft tumors. The results showed that there was a 3 -fold decrease in tumor volume in BAP1 knockdown mice compared to mice bearing control xenografts [23]. Furthermore, following cell injection via the tail vein, OCM1A cells with BAP1 knockdown elicited 2-fold less metastasis to the lungs and 1.5-fold less to the liver compared to control mice. The group then examined melanocytic properties in BAP1 depleted uveal melanoma cells. With BAP1 depletion, the cells had morphological changes where there were fewer dendritic aborizations and significantly less differentiated spindle morphology [23]. The authors concluded that uveal melanoma cells with BAP1 depletion were undergoing a loss of cell identity, however, it remains unknown how this leads to metastasis and an aggressive cancer. It may be due to the disruption of genetic and epigenetic changes that usually prevent the melanocytes from migrating towards distal sites following the loss of cell identity. However, to test this hypothesis a BAP1 knockout animal model needs to be developed to model the metastasis of the tumor cells from the eye.

\section{Conclusion}

Uveal melanoma is a malignant cancer found in the eye and effects approximately 2-8 million people worldwide annually. When the melanoma is associated with metastasis, the prognosis is poor with a high mortality rate. Researchers have begun to examine potential targets in metastatic uveal melanoma to improve the overall prognosis. One such target is BAP1 which has been identified in approximately $18-45 \%$ of cases. Importantly, BAP1 loss led to the dysregulation of the cell cycle, a decrease in the volume of uveal melanoma xenograft tumors and a decrease in metastases to the liver and lungs. Therefore, BAP1 or its downstream proteins could prove to be a future drug target. Thus, future studies should further examine mechanism(s) of BAP1 loss and potential BAP1-mediated treatments in uveal melanoma.

\section{References}

1. Virgili G, Gatta G, Ciccolallo L, Capocaccia R, Biggeri A, et al. (2008) Survival in patients with uveal melanoma in Europe. Arch Ophthalmol 126(10): 1413-1418.

2. Damato B, Coupland SE (2009) A reappraisal of the significance of largest basal diameter of posterior uveal melanoma. Eye 23(12): 21522160 .

3. Shields CL, Furuta M, Thangappan A, Nagori S, Mashayekhi A, et al. (2009) Metastasis of uveal melanoma millimeter-by-millimeter in 8033 consecutive eyes. Arch Ophthalmol 127(8): 989-998.

4. Singh AD, Turell ME, Topham AK (2011) Uveal melanoma: trends in incidence, treatment, and survival. Ophthalmol 118(9): 1881-1885.

5. Kaliki S, Shields CL, Shields JA (2015) Uveal melanoma: estimating prognosis. Indian J Ophthalmol 63(2): 93-102.

6. Kolandjian NA, Wei C, Patel SP, Richard J, Dett T, et al. (2013) Delayed systemic recurrence of uveal melanoma. Am J Clin Oncol 36(5): 443449.

7. Helgadottir H, Hoiom V (2016) The genetics of uveal melanoma: current insights. Appl Clin Genet 9: 147-155.

8. Harbour JW, Onken MD, Roberson EDO, Duan S, Cao L, et al. (2010) Frequent mutation of BAP1 in metastasizing uveal melanoma. Science 330 (6009): 1410-1413.

9. Martin M, Masshofer L, Temming P, Rahmann S, Metz C, et al. (2013) Exome sequencing identifies recurrent somatic mutations in EIF1AX and SF3B1 in uveal melanoma with disomy 3. Nat Genet 45(8): 933936.

10. Gupta MP, Lane AM, DeAngelis MM, Mayne K, Crabtree M, et al. (2015) Clinical characteristics of uveal melanoma in patients with germline BAP1 mutations. JAMA Ophthalmol 133(8): 881-887. 
11. Testa JR, Cheung M, Pei J, Below JE, Tan Y, et al. (2011) Germline BAP1 mutations predispose to malignant mesothelioma. Nat Genet 43(10): 1022-1025.

12. Van de Nes JA, Nelles J, Kreis S, Met CH, Hager T, et al. (2016) Comparing the prognostic value of BAP1 mutation pattern, chromosome 3 status, and BAP1 immunohistochemistry in uveal melanoma. Am J Surg Pathol 40(6): 796-805

13. Koopmans A, Verdik R, Bosch T, Berg M, Vaarwater J, et al. (2013) BAP1 mutations in uveal melanoma. Invest Ophthalmol Vis Sci 54(15): 4223.

14. Landreville S, Agapova OA, Matatall KA, Kneass ZT, Onken MD, et al (2012) Histone deacetylase inhibitors induce growth arrest and differentiation in uveal melanoma. Clin Cancer Res 18(2): 408-416.

15. Bott M, Brevet M, Taylor BS, Shimizu S, Ito T, et al. (2011) The nuclea deubiquitinase BAP1 is commonly inactivated by somatic mutations and 3p21.1 losses in malignant pleural mesothelioma. Nat Genet 43(7): 668-672.

16. Iwanaga $\mathrm{R}$, Komori $\mathrm{H}$, Ishida $\mathrm{S}$, Okamura $\mathrm{N}$, Nakayama KI, et al (2006) Identification of novel EF1 target genes regulated in cell cycledependent and independent manners. Oncogene 25(12): 1786-1798.

17. Machida YJ, Machida Y, Vashist AA, Wohlschlegel JA, Dutta A (2009) The deubiquitinating enzyme BAP1 regulates cell growth via interaction with HCF-1. J Biol Chem 284(49): 34179-34188.
18. Misaghi S, Ottosen S, Izrael-Tomasevic A, Arnott D, Lamkanfi M, et al. (2009) Association of C-terminal ubiquitin hydrolase BRCA1associated protein 1 with cell cycle regulator host cell factor 1 . Mol Cell Biol 29(8): 2181-2192.

19. Carbone M, Yang H, Pass HI, Krausz T, Testa JR, et al. (2013) BAP1 and cancer. Nat Rev Cancer 13(3): 153-159.

20. Tyagi S, Chabes AL, Wysocka J, Herr W (2007) E2F activation of S phase promoters via association with HCF-1 and the MLL family of histone H3K4 methyltransferases. Mol Cell 27(1): 107-119.

21. Pardo M, Pineiro A, De la Fuente M, Garcia A, Prabhakar S, et al. (2004) Abnormal cell cycle regulation in primary human uveal melanoma cultures. J Cell Biochem 93(4): 708-720.

22. Pan $H$, Jia R, Zhang $L, X u S, W u$ Q, et al. (2015) BAP1 regulates cell cycle progression through E21 target genes and mediates transcriptional silencing via H2A monoubiquitination in uveal melanoma cells. Int Biochem Cell Biol 60: 176-184.

23. Matatall KA, Agapova OA, Onken MD, Worley LA, Bowcock AM, et al. (2013) BAP1 deficiency causes loss of melanocytic cell identity in uveal melanoma. BMC Cancer 13: 371.

\section{Your next submission with Juniper Publishers will reach you the below assets}

- Quality Editorial service

- Swift Peer Review

- Reprints availability

- E-prints Service

- Manuscript Podcast for convenient understanding

- Global attainment for your research

- Manuscript accessibility in different formats

(Pdf, E-pub, Full Text, Audio)

- Unceasing customer service

Track the below URL for one-step submission https://juniperpublishers.com/online-submission.php 